UDC 792. 077 (477)

\section{Цитування:}

Ян I. М. Культуротворча та етноконсолідуюча роль українського музично-драматичного театру у соціосфері України останньої третини XIX початку XX століття. Вісник Національної академії керівних кадрів культури і мистецтв : наук. журнал. 2021. № 1. С. 156-159.

Yan I. (2021). Cultural and ethnic-consolidating role of Ukrainian music and drama theater in the sociosphere of Ukrainian in the last third of the XIX - beginning of XX century. National Academy of Culture and Arts Management Herald: Science journal, 1, 156-159 [in English].
Yan Iryna,

Candidate of Art Criticism, Associate Professor

of the «Pavlo Chubynsky Academy of Arts》

ORCID: https://orcid.org/0000-0003-0416-6625

iniko2004@gmail.com

\title{
CULTURAL AND ETHNIC-CONSOLIDATING ROLE OF UKRAINIAN MUSIC AND DRAMA THEATER IN THE SOCIOSPHERE OF UKRAINIAN IN THE LAST THIRD OF THE XIX - BEGINNING OF XX CENTURY
}

The purpose of the article is devoted to the study of the cultural and ethnic-consolidating role of Ukrainian music and drama theatre in the sociosphere of Ukraine in the multicultural conditions of the Russian and Austro-Hungarian empires in the last third of the XIX - beginning of XX century. The methodology of research consists in the application of historical and cultural, comparative, systematic methods, which provide an opportunity to reveal the specifics of the constitution of music and drama theatre of the sociosphere of society. The scientific novelty of the work lies in the study of culture-forming activities of music and drama groups in the context of nation-building in the system of socio-cultural interactions. Conclusions. At times of total state and censorship bans, Ukrainian music and drama theatre, integrating into the cultural and historical form of a multicultural society, acquired the status of a sociocultural phenomenon, that performs an ethnic-consolidating role, promoted the preservation of Ukrainian cultural traditions, national self-affirmation, and became an important factor in ethnocultural identification.

Key words: Ukrainian music and drama theatre; national-cultural revival; national identity; sociosphere; traditions; repertoire.

Ян Ірина Миколаївна, кандидат мистеитвознавства, доцент КЗВО КОР «Академія мистеитв імені Павла Чубинського»

Культуротворча та етноконсолідуюча роль українського музично-драматичного театру у соціосфері України останньої третини XIX - початку XX століття

Мета роботи. Статтю присвячено дослідженню культуротворчої та етноконсолідуючої ролі українського музично-драматичного театру у соціосфері України в полікультурних умовах Російської та Австро-Угорської імперій в останній третині XIX - початку XX століття. Методологія дослідження полягає у застосуванні історико-культурного, компаративного, системного методів, які надають можливість розкрити специфіку конституювання музично-драматичного театру у соціосфері суспільства. Наукова новизна роботи полягає у дослідженні культуротворчої діяльності музично-драматичних колективів у контексті націєтворення в системі соціокультурних взаємодій. Висновки. Український музично-драматичний театр у час тотальних державних та цензурних заборон, інтегруючись у культурно-історичну форму полікультурного суспільства, став яскравим феноменом національної художньої культури, сприяв національному самоутвердженню, збереженню культурно-історичних традицій української нації.

Ключові слова: український музично-драматичний театр; національно-культурне відродження; національна ідентичність; соціосфера; традиції; репертуар.

The topicality of the research. Ukrainian historical and cultural heritage, which has been formed over the centuries, is the main component of national self-identification and representation of our country in common European space.
Ukrainian music and drama theatre is an integral part of the cultural and historical heritage of Ukraine, a means to preserve ethnic traditions, aesthetic cognition, worldview values. The study of its historical foundations as a cultural 
phenomenon that can illustrate the dynamics of the Ukrainian nation's spiritual progress in the current context of national and cultural identification and European integration of Ukraine is quite important today and is one of the priorities of modern art history.

The works of D. Antonovich [2], N. Andrianova [1], V. Vasulko [4], A. Krasylnikova [8], B. Romanytsky [14], and others reveal the historical and cultural preconditions for the formation of Ukrainian theatre art. The works of V. Burdulanyuk [3], I. Chernichko [18], S. Chornyi [19], V. Shurapov [20], and others are devoted to certain aspects of the Ukrainian theatre art development in the context of national and cultural revival. At the same time, despite the importance of the scientists' work, the cultural aspect of the formation and development of the Ukrainian music and drama theatre in the sociosphere of Ukraine still needs art analysis. This is the reason for choosing the topic for the article which aims to study the cultural and ethnicconsolidating role of Ukrainian music and drama theatre in the sociosphere of Ukraine in the multicultural conditions of the Russian and Austro-Hungarian empires in the last third of the XIX - beginning XX centuries.

Presentation of the basic material. In the analyzed period, Ukrainian music and drama theatre became a powerful source of indomitable national spirit, because the socio-political and national-cultural conditions in which the Ukrainian community existed in the Russian Empire, were aimed at colonizing the Ukrainian culture. Ukrainian culture as a powerful national system was severely persecuted by the imperial government, state authorities, which organized a corresponding legislative framework specifically for it, the purpose of which was the integration of Ukrainians into imperial society, resulting in the unification of historical memory, national identity, and prospects of the Ukrainian nation [18, 40].

The system of imperial legislative, executive, and judiciary authority tried to hinder the development of the Ukrainian music and drama theatre. Official state documents (circulars, orders, statutes) were aimed at regulating activity, announcing requirements for current repertoire and charitable musical-dramatic performances, requirements for musical-dramatic repertoire [6, 78; 79].

In the conditions of cultural colonization, it was extremely difficult for theatre artists to get permission to stage Ukrainian plays, as it was necessary to obtain a decision from the entire censorship apparatus. In particular, the permit was issued by the local authority, which in turn was guided by regulatory state directives, circulars and worked closely with the Main Directorate for Press Affairs, the Censorship Committee. The Main Directorate for Press Affairs and the Censorship Committee carefully checked the theatre repertoire following the legislative documents and the power granted to them, and those stage works that did not correspond to the ideological context of the state withdrew from circulation or at best were returned to the author for revision [6, 77].

In addition to legislative and censorship bans, Ukrainian troupes were hampered by administrative harassment, which banned theatre performances during the calendar year, mainly during church holidays. Surely, all these restrictions have left their mark on the schedule and geography of touring trips of Ukrainian music and drama groups [7, 39]. Thus, the created censorship system, tightly regulating theatre activities, was only an instrument of power that effectively protected it, ensuring Russification policy in Ukraine, while sacrificing national interests: public, scientific, educational, cultural.

During the period of its formation and constitution (late XIX - beginning XX century), music and drama theatre becomes a powerful source of indomitable national spirit, artistic carrier of Ukrainian culture, performing the cultural and ethnic-consolidating role in the sociosphere of that time society. Outstanding theatre artists M. Kropyvnytskyi, M. Starytskyi, M. Sadovskyi， M. Zankovetska， P. Saksahanskyi adhering the cultural and historical traditions of T. Shevchenko and I. Kotlyarevskyi, to preserve national identity, sought to protect the social rights, the language, and culture of Ukrainian people. They focused their creative activity on bringing Ukrainian theatre culture to the European path of development, developing national style in their work, popularizing Ukrainian artistic heritage among the general population of the polyethnic society, which contributed to the preservation of ethnicity, nation formation, and interethnic dialogue of cultures. Due to the creative work of national theatre figures in the analyzed period, Ukrainian theatre culture represents itself to society, creates a powerful cultural potential.

The outstanding theatre personalities M. Kropyvnytskyi, M. Starytskyi, M. Sadovskyi, M. Zankovetska, P. Saksaganskyi made efforts to preserve the ethnocultural identity, folk son, $g$ and folklore tradition, the opportunity to have their theatre school. In the process of constituting the national theatre specifics, they used all their creative tools - musical-dramatic, folk-domestic 
specifics of the repertoire, ethnographic nature of scenery, costumes, choreographic design of performances, defining the principles of Ukrainian theatre as musical-dramatic one. The musical and poetic specifics of the direction of the Ukrainian stage contributed to the involvement of talented composers

M. Vasiliev-Sviatoshenko, M. Lysenko, P. Nishchynskyi, and M. Arkas in the staging process $[16,30 ; 55]$.

The national character became a solid foundation or artistic and aesthetic system of Ukrainian music and drama theater, based on which the national repertoire, artistic form of musical and dramatic performance, principles of performance, scenography and directing, nature of scenery, costumes, choreographic design of performances. The national specificity of theatre performances was notable for the skillful addition of bright means of expression to the dramatic action: vocal and musical (musical pictures, folk songs), choreographic (divertissement, folk dance, choreographic composition) [16, 12-13].

The decor was an important organic component of the dramatic variety of Ukrainian music and drama theater with its syncretic character. In conditions of continuous imperial oppression, aimed at the destruction of the Ukrainian ethnos and Ukrainian culture, national scenery in combination with acting, music, and choreography promoted ethnographic features, customs of Ukrainians, which contributed to the realization of their own national identity. National decorative design in Ukrainian music and drama performances created the ethnographic and everyday atmosphere of the stage action, contributed to the authentic, deep disclosure of the artistic content of the work, and had a direct impact on the audience.

An important direction of Ukrainian music and drama theatre activity was the establishment of interethnic connections. Intercultural dialogue in the sociosphere of theatre manifested itself in the following forms of communication: the establishment of creative contacts between Ukrainian and Polish artists, exchange of directing and acting experience, staging musical and dramatic performances "Galka" by S. Moniushko, "Mazepa" by Yu. Slovatskyi, "The Enchanted Circle", "From a Good Heart" by L. Riedel [5, 33].

At the beginning of the twentieth century, Ukrainian theatrical art was promoted among the public by the followers of the luminaries of the Ukrainian stage - professional music and drama troupes of D. Gaidamaka, I. Ivas-Moroz, P. Kasynenko, Yu. Karpenko, O. Suslova, T. Chernyshov and others. The artists were united not only by common art interests but also by the desire to serve the cause of national and cultural revival. Due to this, the ideological influence of outstanding Ukrainian artists, the aesthetic spirit of their work was felt in the activity of theatrical groups. This is how continuity in Ukrainian theatrical culture was asserted.

Performances of Ukrainian music and drama groups were essentially national, artistic, aesthetic, and educational. The originality of the plot, the intensity of the dramatic action, the presence of vital authentic stage images were combined with folklore motifs, songs, and rituals. The original Ukrainian repertoire had a bright ethnographic and everyday orientation, reflected the national type of Ukrainians, promoted their traditions, rituals and was understandable and extremely popular among the public.

The repertoire was based on plays: "Natalka Poltavka" by I. Kotlyarevskyi, "Matchmaking in Goncharivka" by G. Kvitka-Osnovyanenko, "Give Freedom to Your Heart, and It Will Lead to Captivity", "The Courtship of Sotskyi Musii" (Songs in the faces), "After Revision" by M. Kropyvnytskyi, "Vechornytsi" by P. Nishchynskyi, "Bohdan Khmelnytskyi", "Marusia Bohuslavka", "Sorochyntsi Fair", "It Did not Turn out as Desired", "Kupala Night", "Oh, Do not Go Hryts to Vechornytsi" by M. Starytskyi and others $[19,132]$.

Ukrainian music and drama groups of D. Gaidamaka, I. Ivas-Moroz, P. Kasynenko, Yu. Karpenko, O. Suslova, T. Chernyshov, and others launched active touring activities in St. Petersburg, Kursk, Saratov, Kharkiv, Odesa, Volga region (Symbirsk, Saratov, Samara), the Far East (Khabarovsk, Irkutsk), and other cities and localities of the Russian and AustroHungarian empires, that were aimed at promoting the ethnocultural identity of the Ukrainian nation, involving a wide range of polyethnic communities in the Ukrainian theatrical art. In many places, where the Ukrainian language has never been heard, musical and dramatic performances were a real holiday for Ukrainians living in these territories and for the polyethnic community [20, 92-93]. The performances have always been sold out. Thus, the activities of prominent national theatrical figures popularized Ukrainian culture among a wide range of polyethnic audiences.

Conclusions. At times of total state and censorship bans, Ukrainian music and drama theatre, integrating into the cultural and historical form of a multicultural society, acquired the status of a socio-cultural phenomenon, that performs an ethnic-consolidating role, promoted the preservation of Ukrainian cultural traditions, 


\section{Вісник Національної академії керівних кадрів культури і мистецтв № 1’2021}

national self-affirmation, and became an important factor in ethnocultural identification.

\section{Jimepamypa}

1. Андріанова Н. М. Шляхи розвитку українського театру. Київ : Знання, 1960. 40 с.

2. Антонович Д. Триста років українського театру, 1619-1919. Прага : Укр. громад. видавничий фонд, 1925. $272 \mathrm{c}$.

3. Бурдуланюк В. М. Культурні зв'язки Галичини з Наддніпрянською Україною в кінці XIX - на початку XX ст. : автореф. дис. ... канд. іст. наук: спец. 07.00.01. Чернівці, 1996. 24 с.

4. Василько В. С. Театру віддане життя. Київ : Мистецтво, 1987. 407 с.

5. Горбатовський П. Стаціонарний польський театр у Києві 1905-1914 років // Вісник Львівського університету. Серія : Мистецтвознавство. 2005. Вип. 5. С. 19-44.

6. Державний архів Одеської області. Ф. 5. оп. 1. Спр. 1689, арк. 77-79.

7. Державний архів Одеської області. Ф. 2. оп. 1. Спр. 1504, арк. 39.

8. Клековкін О. Періодизація і метод історії театру: маркери. Вісник Національної академії керівних кадрів культури і мистецтв. 2020. №1. С. 34-39.

9. Красильникова О. В. Історія українського театру XX сторіччя. Київ : Либідь, 1999. 208 с.

10. Кропивницький Марко Лукич Твори. У 6ти т. Київ : Держлітвидав. УРСР, 1958-1960. Т. 6. $1960.672 \mathrm{c}$.

11. Малюта О. «Просвіти» i Українська Державність (друга половина XIX - перша половина $\mathrm{XX}$ ст.): до 140-річчя товариства «Просвіта» : монографія. К. : Просвіта, 2008. 840 с.

12. Новиков А. О. Українська драматургія й театр від найдавніших часів і до початку XX ст. : монографія. Харків : Сага, 2011. 408 с.

13. Реєнт О. П. Україна в імперську добу (XIX - початок XX століття). Київ, 2016. 320 с.

14. Романицький Б. В. Український театр в минулому і тепер. Київ : Держполітвидав УРСР, $1950.63 \mathrm{c}$.

15. Саксаганский П. К. Из прошлого украинского театра. М. ; Л. : Искусство, 1938. 167 с.

16. Сидоренко В. Нариси 3 історії театрального мистецтва України ХX ст. К. : Інтертехнологія, 2006. 1054 с.

17. Старицький М. П. Твори. У 8 т. Т. 8. Оповідання, статті, листи. Київ : Держ. вид-во худ. літ., 1965. 751 с.

18. Черничко I. В. Трансформація сфери культури: українська національна театральна культура: стан, статус, інфраструктура, модернізація. Київ, 1998. 147 с.

19. Чорній С. Український театр і драматургія. Мюнхен; Нью-Йорк, 1980. 248 с.

20. Шурапов В. Марко Кропивницький та його спадкоємці: історичний нарис. Кіровоград : КОД, 2010. 392 с.

\section{References}

1. Andrianova, N. (1960). Ways of Ukrainian theatre development. Kyiv: Knowledge [in Ukrainian].

2. Antonovych, D. (1925). Three hundred years of Ukrainian theatre, 1619 - 1919. Prague [in Ukrainian].

3. Burdulanyuk, V. M. (1996). Cultural connection with Galicia from Naddniprianschyna in the of late XIX-beginning XX century. Ivano-Frankivsk [in Ukrainian].

4. Vasulko, V. (1987). Theatre devotional life. Kiev: Art [in Ukrainian].

5. Gorbatovsky, P. (2006). From amateur circle to professional theatre. Lviv [in Ukrainian]

6. DAOR. F. 5. Op.1. Spr. 1689. ark. 77-79 [in Ukrainian].

7. DAOR. F. 5. Op.1. Spr. 1504. ark. 39 [in Ukrainian].

8. Klekovkin O. (2020). Periodization and method of history of theater: markers. National Academy of Managerial staff of culture and Arts Herald: Science journal, 1, 34-39 [in Ukrainian].

9. Krasylnykova, O. (1999). History of Ukrainian theatre of the XX century. Kyiv: Lybid [in Ukrainian].

10. Kropyvnytskyi, M. L. (1968). Works. Kyiv: Derzhpolitvydav [in Ukrainian].

11. Maliuta, O. (2008). "Enlightenments" and the Ukrainian state (the second half of XIX - early XX century). Kyiv: Education [in Ukrainian].

12. Novykov, A. (2011). Ukrainian drama and theatre from ancient times to the early XX century. Kharkiv: Osnova [in Ukrainian].

13. Reient, O. (2003). Ukraine in the imperial epoch (XIX - the beginning of XX century). Kyiv [in Ukrainian].

14. Romanytskyy, B. (1950). Ukrainian theatre in the past and nowadays. Kyiv: D'erzhpolitvydav URSR [in Ukrainian].

15. Saksaganskiy, P. (1938). Since the last Ukrainian theater. M.: Art [in Russian].

16. Sidorenko, V. (2006). Essays on the history of theatrical art of Ukraine of the twentieth century. Kyiv [in Ukrainian].

17. Starytskyi, M. (1965). Works. Kyiv: Dnipro [in Ukrainian].

18. Chernichko, I. V. (1998). Transformation of the sphere of culture: Ukrainian national theatrical culture: status, infrastructure, modernization. Kyiv: National Academy of Sciences [in Ukrainian].

19. Chornyi, S. (1980). Ukrainian theatre and drama. Munich, New York [in Ukrainian].

20. Shurapov, V. (2002). 120 years of Mark Kropyvnytskyi Theatre. Kirovohrad: "Kod" [in Ukrainian].

Стаття надійшла до редакиії 14.12.2020 Отримано після доопрацювання 05.01.2021 Прийнято до друку 12.01.2021 